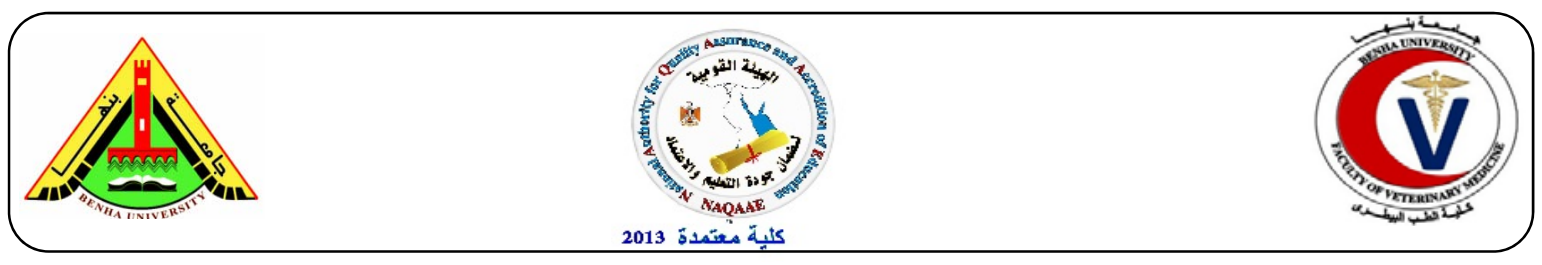

\title{
Prevalence and molecular analysis of anaplama and piroplasmid species infecting buffaloes in qualyubia governorate, Egypt
}

\author{
Nagwa E. A. ${ }^{1}$, Ghanem M. M. ${ }^{2}$, Elmadawy R. S. ${ }^{1}$, ELdiarby A. S. ${ }^{3}$ \\ ${ }^{1}$ Parasitology Department, Faculty of Veterinary medicine, Benha University. ${ }^{2}$ Animal Medicine \\ Department, Faculty of Veterinary medicine, Benha University. ${ }^{3}$ Veterinary Teaching Hospital, Faculty \\ of Veterinary Medicine, Benha University.
}

\section{A B S T R A C T}

This study aimed to investigate the prevalence of Anapalsma and piroplasmid species infecting buffaloes with regard to season, age and sex. To achieve this aim, blood samples from a total of 530 apparently healthy and clinically suspected buffaloes in Qualyubia governorate, Egypt were collected throughout the period from June 2013 to May 2014. The blood samples were smeared, stained with Giemsa and examined by conventional microscope. Moreover, PCR assay was applied to amplify DNA of Babesia and Theileria sp. in 100 microscopically negative buffaloes' blood samples. The microscopic investigation identified the infection in $37.92 \%$ of the examined buffaloes. Anaplasma marginale was the most prevalent species (30.94\%) followed by Babesia sp. (26.60\%) and Theileria annulata $(2.08 \%)$. The most frequent clinical signs observed during the course of disease, in addition to the effect of seasons, age and sex on the prevalence of infection were presented in the study. PCR assay proved to be the most reliable method for the diagnosis of piroplasmid infections as compared to light microscopy, where it was able to detect Babesia and Theileria sp. DNA in $25 \%$ and $12 \%$ with $5 \%$ mixed in the microscopically negative blood samples of buffaloes respectively. The high prevalence of infection in buffaloes highlights the need for establishment of a consolidated control program to overcome the economic losses caused by these parasites.

Key words: Buffalo, Piroplasmosis, Prevalence, PCR.

(http://www.bvmj.bu.edu.eg) $\quad$ (BVMJ-30(1): 86-96, 2016)

\section{INTRODUCTION}

A naplasma, Babesia, Theileria and are tick- borne parasites which have a diverse distribution throughout the world, mainly in tropical and subtropical countries and have a great impact on bovine production (Mehlhorn and Schein, 1984). Anaplasma marginale is a rickettsial hemolytic disease infecting bovine caused by Anaplasma marginale (Rickettsiales: Anaplasma taceae) (Kocan, et al., 2000). A. marginale can lead to death of adult animals and economics losses including decreased weight gain, abortions, bull infertility as well as costly treatment. The genus Babesia includes more than 100 species of pathogenic protozoa that infect RBCs of a wide range of hosts (Spielman et al.,1985); This includes B. bigemina and B. bovis which have a significant impact on bovine health and production (Iseki et al 2010), they can result in clinical disease and carrier cases (Goff et al., 2008), However, B. bovis is more pathogenic than $B$. bigemina (Chaudhry et al., 2010). Theileria parva and T. annulata are the most pathogenic species infecting bovine and they are of great economic importance causing mild or severe infection to infected hosts (Altay et al., 2008 and Safieldin et al., 2010). They cause lymphoprolipherative disease with high morbidity and mortality rates, generally known as tropical theileriosis. 
Microscopy is considered the gold standard using Giemsa stained blood films for excellent demonstration of the parasites especially in acutely infected cases (Böse et al., 1995). This aforementioned method is of a low sensitivity which discourage its use in epidemiological surveys (Almeria et al., 2001). So the use of more innovative diagnostic tools are more effective (Weiland and Reiter,1988). The aim of this current study is to investigate the prevalence of Anaplasma and piroplasm infections in buffaloes (Bubalus bubalis) using two diagnostic techniques: microscopic examination and PCR molecular tools, together with the evaluation of the effect of seasons, age and sex on the infection rate in Qualyubia governorate, Egypt.

\section{MATERIALS AND METHODS}

\subsection{Animals}

This present work was conducted throughout the period from June 2013 to May 2014. A total of 530 Egyptian water buffaloes (Bubalus bubalis) (129 clinically suspected and 401 apparently healthy) of different ages and sex (348 Male and 182 Female) were examined for Anaplasma and piroplasmid infections. Buffaloes were obtained from three localities in Qualyubia Governorate (Shebin-Elkanater, Toukh and Benha), as well as, from those admitted to the Teaching Hospital in the Faculty of Veterinary Medicine, Benha University.

\subsection{Blood Samples}

Blood samples were collected directly the jugular vein of each buffaloe in anticoagulant test tubes containing Disodium EDTA to be used for preparing of blood smears and for PCR technique. The Blood samples used for PCR assay were stored at $-20^{\circ} \mathrm{c}$ for DNA extraction.

\subsection{Microscopic examination}

A thin blood films were prepared from each sample and left to dry. The numbered smears were labeled by place of collection, date, age and sex of the examined buffaloes.
In the laboratory, the blood smears were fixed in absolute methanol for 5-7 $\mathrm{min}$, stained with freshly diluted and filtered Giemsa stain for 30-45 minutes, then washed with distilled water and finally, they were air dried (Coles, 1986). The intraerthrocytic stages of Babesia and Theileria sp. were examined and measured in each slide using eye piece micometer under 100X objective lens. Calculating the percentage of different forms of Babesia sp. was done by counting the different forms of Babesia inside $100 \mathrm{RBCs}$; the process was repeated in 20 slides and the average was taken (Baur et al.,1974). If no parasites were detected in 50 oil-immersion fields in three blood smears, the smears were recorded as negative for piroplasms (Altay et al., 2008).

\subsection{Molecular methods}

To evaluate the accuracy of molecular diagnosis, one hundred microscopicallynegative blood samples obtained from 43 clinically suspected and 57 apparently healthy buffaloes were submitted for examination by PCR methods to amplify Babesia and Theileria sp. DNA in the tested samples.

\subsubsection{DNA extraction}

DNA was extracted from whole anticoagulated blood using genomic DNA kits (Peqgold, Germany) according to manufacturer's instructions. Multiplex primers (Promega, USA); forward primer BAB GF2 (5GTCTTGTAATTGGAATGATGG-3) and the reverse primer $\mathrm{BAB}$ GR2 (5CCAAAGACTTTGATTTCTCTC-3) were used for amplification of $350 \mathrm{bp}$ of Babesia and $370 \mathrm{bp}$ of Theileria (Adaszek and Winiarczyk, 2008). In brief, each reaction mixture $(50 \mu \mathrm{L})$ contains $1.6 \mathrm{mM}$ of $\mathrm{MgCl}$ $2,100 \mu \mathrm{M}$ of each dNTP, $0.25 \mu \mathrm{M}$ of each primer, $5 \mu \mathrm{L}$ of DNA template and $2.5 \mathrm{ul}$ of Taq polymerase. The amplification was done in a thermal cycler with the following steps: an initial denaturation for 2 minutes at $92^{\circ} \mathrm{c}, 50$ cycles of denaturation for 60 seconds at $92^{\circ} \mathrm{c}$, annealing for 60 seconds 
at $52^{\circ} \mathrm{c}$, primary extension for 90 seconds at $72^{\circ} \mathrm{c}$, final extension for 5 minutes at $72^{\circ} \mathrm{c}$. Negative and Positive controls were included in the assay. PCR results were assessed by ethidium bromide stained gel electrophoresis (2\%) and 100-bp DNA ladder (Amersco, Cleveland Ohio, USA).

\subsection{Statistical analysis}

The data were statistically analyzed using chi-squared X2 test (Steel and Torie, 1981).

\section{RESULTS}

The microscopic examination of Giemsa stained blood smears of 530 buffaloes revealed that $88 / 129(68.21 \%)$ clinically suspected, 113/ 401 (28.18\%) apparently healthy animals were infected with Anaplasma marginale, Babesia sp., and Theileria annulata with an overall prevalence of $37.92 \%$. The frequency distribution of the major clinical symptoms observed in acutely infected and carrier buffaloes were presented in Table (1) and Plate (II). Anaplasma marginale was the most prevalent species (30.94\%) followed by Babesia sp. (26.60\%) (Babesia bigemina in $12.07 \%$, Babesia bovis in $8.49 \%$ and mixed infection of both species was noticed in $6.04 \%$ of buffaloes) and T. annulata (2.08\%) (Table.2). An overall mixed infection between different species was recorded in $27.73 \%$ (147/ 530) of buffaloes (Chart.1). The highest prevalence of $A$. marginale, Babesia sp. and T. annulata (40\% and 48.89 and $8.89 \%$ respectively, including single and mixed infections) were observed in animals over 5 years old (Table 3), though no significant difference was recorded except at age of 2-5 years $(P<0.05)$. A significant variation $(P<0.05)$ was recorded in different seasons of the year, where $A$. marginale showed the highest prevalence in winter season (39.71\%, representing single and mixed infections), whilst Babesia sp. and $T$. annulata exhibited the highest rate in summer (36.576 and $2.99 \%$ respectively, representing single and mixed infections).
Generally, blood parasites were more prevalent in winter and summer (45.59 and $43.28 \%$, respectively) than autumn and spring (Table 4). Moreover, The highest prevalences of A. marginale and Babesia sp. were more detectable in females than males, while T.annulata showed complete absence of the infection among males (Table.5), nevertheless the significant difference $(P<0.05)$ was observed in Babesia sp. and T. annulata, but it was not recorded for $A$. marginale.

\subsection{Morphology of the detected species}

A. marginal is intra erythrocytic rounded bodies $0.29-1.0 \mu \mathrm{m}$ in diameter and mainly situated on or near the margin of the erythrocyte. B. bovis was measured $1.6 \mathrm{X} 1$ $\mu \mathrm{m}$ and B. bigemina; $4 \mathrm{X} 2.1 \mu \mathrm{m}$, they were characterized by variable intraerthrocytic forms (doubled pear shape which constituted $32 \%$, single pear shaped form; $23 \%$, rounded form; $13 \%$, amoeboid form; $10 \%$ ). Theileria annulata was mainly diagnosed by their small size within erythrocytes, the piroplasms were mostly round $(0.5-2.7 \mu \mathrm{m})$ or oval $(2 \mathrm{X} 0.5 \mu \mathrm{m})$ in shape, these forms were more common than rod and comma $(1.3 \mathrm{X} 0.4 \mu \mathrm{m})$ shape forms which had been rarely recognized. The schizonts of $T$. annulata were circular in shape and observed both as free forms and intracellular forms in the lymphocytes within the blood smears. The detected blood species were demonstrated in Plate I.

\subsection{PCR assay}

It was confirmed through this study that PCR was more sensitive in detecting low level of infections in carrier buffaloes as compared to light microscopy as it was able to detect piroplasmid infections in $22 / 43$ $(51.16 \%)$ of clinically suspected buffaloes and in 20/ $57(35.09 \%)$ apparently healthy ones, which were proved to be negatively infected using conventional microscope. Babesia and Theileria DNA were amplified in 25 and $12 \%$ of buffalo blood samples respectively. Mixed infection was noticed in $5 \%$ of buffaloes (Table. 6 \&Fig. 1). 
Table.1: Frequency distribution of the major clinical symptoms in buffaloes suffering from Anaplasma marginale and Piroplasmid infections

\begin{tabular}{|c|c|c|c|c|c|c|c|c|c|}
\hline \multirow{2}{*}{ Clinical signs } & \multicolumn{2}{|c|}{ A. Marginale } & \multicolumn{2}{|c|}{ Babesia sp. } & \multicolumn{2}{|c|}{ T. annulata } & \multicolumn{2}{|c|}{$\mathrm{B}+\mathrm{A}$} & \multirow{2}{*}{$\begin{array}{l}\mathrm{B}+\mathrm{T} \\
\mathrm{I}=4\end{array}$} \\
\hline & $\mathrm{C}=377$ & $\mathrm{I}=11$ & $\mathrm{C}=111$ & $\mathrm{I}=20$ & $\mathrm{C}=2$ & $\mathrm{I}=5$ & $C=63$ & $\mathrm{I}=48$ & \\
\hline High temperature & - & 10 & - & 12 & - & 5 & - & 24 & 4 \\
\hline Accelerated heart rate & - & 3 & 2 & ,8 & - & 4 & - & 20 & 3 \\
\hline Increased respiration & - & 1 & & 8 & - & 4 & - & 20 & 3 \\
\hline Icterus & - & 5 & & 5 & - & 3 & 7 & 13 & 3 \\
\hline Haemoglobinurea & - & - & & 10 & - & 1 & - & 12 & 4 \\
\hline Paleness & 4 & - & 2 & 16 & 1 & 5 & 9 & 13 & 4 \\
\hline Alopecia & - & - & - & - & - & 1 & - & - & 1 \\
\hline Cough & - & 1 & - & 6 & - & 2 & 1 & - & 2 \\
\hline Lymphoadenopathy & - & 1 & - & 2 & & 5 & - & - & 4 \\
\hline Inappetance & 3 & 11 & 2 & 12 & 1 & 5 & - & 10 & 4 \\
\hline Recumbency & - & 2 & - & 3 & - & 2 & - & 7 & 1 \\
\hline Corneal opacity & - & - & - & - & - & 5 & - & - & 4 \\
\hline Salivation & - & 1 & 1 & - & - & 1 & - & - & 1 \\
\hline Bloody feces & - & 8 & & - & - & 2 & - & 1 & - \\
\hline
\end{tabular}

Abbreviations: $\mathrm{C}=$ Carrier I $=$ acutely infected, B: Babesia, T: Theileria, A: Anaplasma.

Table (2) Single and mixed infection of A. marginale and piroplasmid species among examined buffaloes

\begin{tabular}{cccc}
\hline Species & $\begin{array}{c}\text { No. infected } \\
\mathrm{N}=530\end{array}$ & $\begin{array}{c}\text { Single infection } \\
\mathrm{N}=530\end{array}$ & $\begin{array}{c}\text { Mixed infection } \\
\mathrm{N}=530\end{array}$ \\
\hline A. Marginale & $164(30.94)$ & $53(10)$ & $111(20.94)$ \\
Babesia $\mathrm{sp}$. & $141(26.60)$ & $26(4.91)$ & $115(21.70)$ \\
T. annulata & $11(2.08)$ & $7(1.32)$ & $4(0.75)$ \\
\hline
\end{tabular}

Values in parentheses represent percentage

Table (3) Prevalence of A. marginale and piroplasmid infections among different age groups of buffaloes.

\begin{tabular}{lrrrrrr}
\hline \multicolumn{2}{l}{ Age(year) Total } & A. marginale & Babesia sp. & T. annulata & \multirow{2}{*}{$\mathrm{B}+\mathrm{A}$} & \multirow{2}{*}{$\mathrm{B}+\mathrm{T}$} \\
\hline$<1$ & 39 & $4(10.26)$ & $5(12.82)$ & $0(0.00)$ & $5(12.82)$ & $0(0.00)$ \\
$1-2$ & 340 & $30(8.82)$ & $5(1.47)$ & $0(0.00)$ & $76(22.35)$ & $0(0.00)$ \\
$2-5$ & 106 & $13(12.26)$ & $7(6.60)$ & $4(3.77)$ & $18(16.98)$ & $3(2.83)$ \\
$>5$ & 45 & $6(13.33)$ & $9(20)$ & $3(6.67)$ & $12(26.67)$ & $1(2.22)$ \\
Total & 530 & $53(10)$ & $26(4.91)$ & $7(1.32)$ & $111(20.94)$ & $4(7.54)$ \\
\hline
\end{tabular}

Values in parentheses represent percentage, Abbreviations: $\mathrm{B}=$ Babesia, $\mathrm{T}=$ Theileria, $\mathrm{A}=$ Anaplasma. Statistical analysis using chi-squared $\mathrm{X} 2$ is considered significant at $\mathrm{P}<0.05$. 
Table (4) Seasonal prevalence of A. marginale and piroplasmid infections among buffaloes.

\begin{tabular}{lcclclll}
\hline Season & Total & A. marginale & $\begin{array}{l}\text { Babesia } \\
s p .\end{array}$ & T.annulata & B+A & B+T & Total \\
\hline Winter & 136 & $35(25.74)$ & $6(4.41)$ & $0(0.00)$ & $19(13.97)$ & $2(1.47)$ & $62(45.59)$ \\
Spring & 131 & $7(5.34)$ & $7(5.34)$ & $1(7.63)$ & $24(18.32)$ & $2(1.53)$ & $41(31.30)$ \\
Summer & 134 & $5(3.73)$ & $6(4.47)$ & $4(2.99)$ & $43(32.09)$ & $0(0.00)$ & $58(43.28)$ \\
Autum & 129 & $6(4.65)$ & $7(5.43)$ & $2(1.55)$ & $25(19.38)$ & $0(0.00)$ & $40(31.01)$ \\
Total & 530 & $53(10)$ & $26(4.91)$ & $7(1.32)$ & $111(20.94)$ & $4(0.75)$ & $201(37.92)$
\end{tabular}

Values in parentheses represent percentage, Abbreviations; B: Babesia, T: Theileria, A: Anaplasma. Statistical analysis using chi-squared X2 is significant at $P<0.05$.

Table (5) Effect of sex on the prevalence of A. marginale and piroplasmid infections among buffaloes.

\begin{tabular}{lccccccc}
\hline Sex & & A. marginale & Babesia sp. & T. annulata & B+A & B+T & Total \\
Total & & & & & & & \\
\hline Female & 182 & $23(12.64)$ & $21(11.54)$ & $7(3.85)$ & $37(20.33)$ & $4(2.20)$ & $92(50.55)$ \\
Male & 348 & $30(8.62)$ & $5(1.44)$ & $0(0.00)$ & $74(21.26)$ & $0(0.00)$ & $109(31.32)$ \\
Total & 530 & $53(10)$ & $26(4.91)$ & $7(1.32)$ & $111(20.94)$ & $4(0.75)$ & $201(37.92)$ \\
\hline
\end{tabular}

Values in parentheses represent percentage, Abbreviations; B: Babesia, T: Theileria, A: Anaplasma. Statistical analysis using chi-squared $\mathrm{X} 2$ is significant at $P<0.05$.

Table (6) Piroplamid species detected by PCR analysis of microscopically negative blood samples obtained from buffaloes.

\begin{tabular}{llll}
\hline Parasites & $\begin{array}{l}\text { Clinically suspected } \\
\mathrm{N}=43\end{array}$ & $\begin{array}{c}\text { Apparently healthy } \\
\mathrm{N}=57\end{array}$ & $\begin{array}{l}\text { Total } \\
\mathrm{N}=100\end{array}$ \\
\hline Babesia sp. & $13(30.23)$ & $12(21.05)$ & $25(25)$ \\
T. annulata & $7(16.28)$ & $5(8.77)$ & $12(12)$ \\
$\mathrm{B}+\mathrm{T}$ & $2(4.65)$ & $3(5.26)$ & $5(5.00)$ \\
Total & $22(51.16)$ & $20(35.09)$ & $42(42.00)$ \\
\hline
\end{tabular}

Values in parentheses represent percentage. Abbreviations; B: Babesia sp., T: Theileria sp., N: Number examined

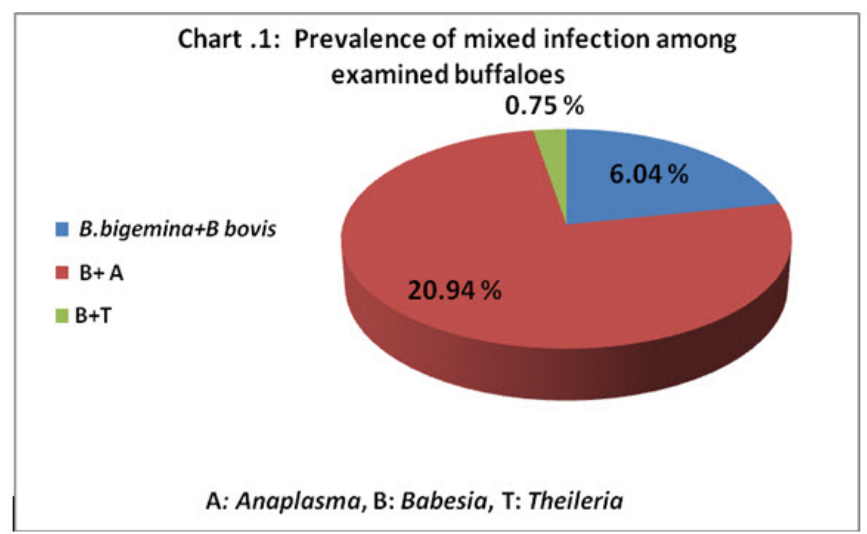




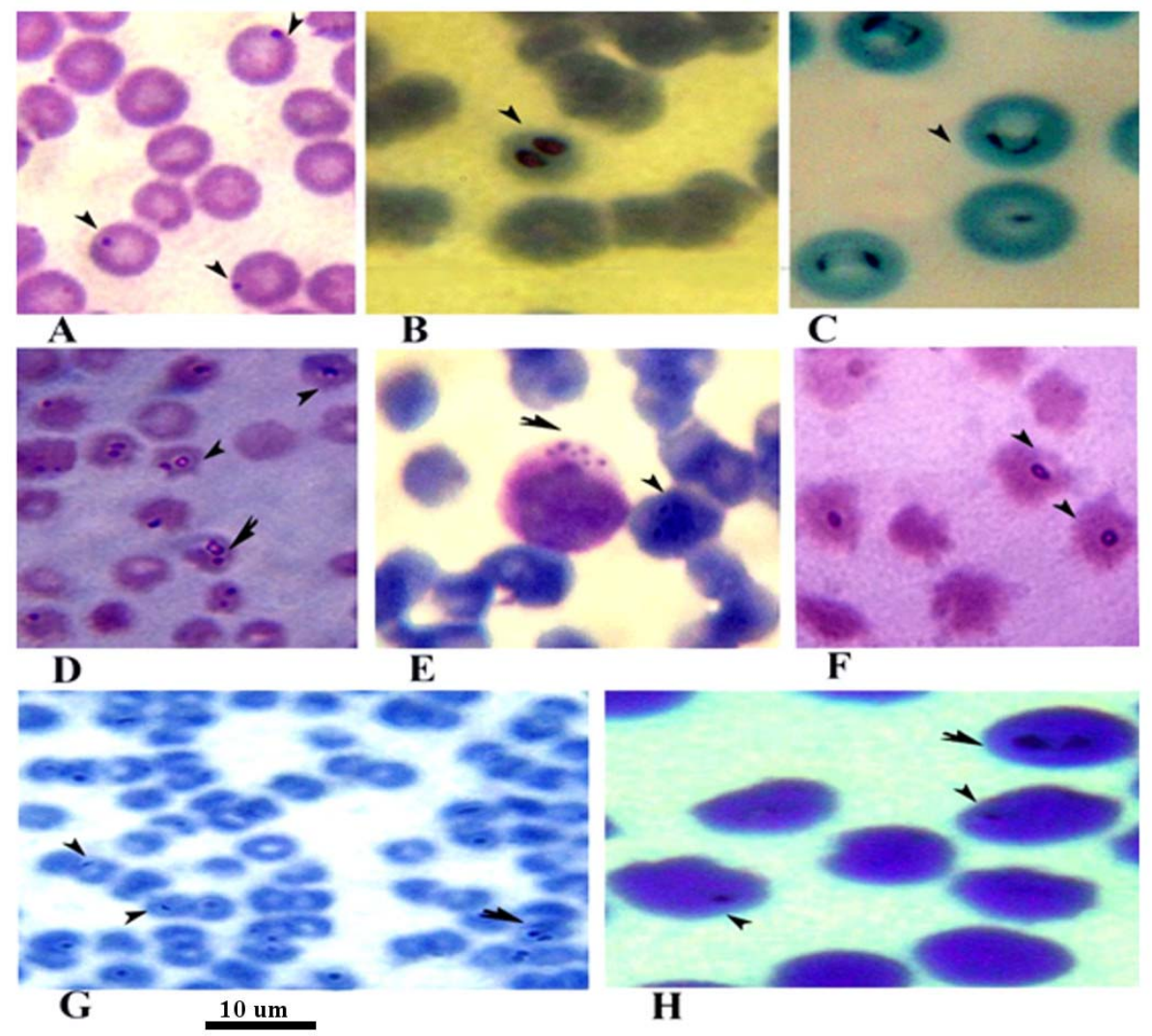

Plate I: A: A. marginale, B: B. bigemina, C: B. bovis , D: different forms of Babesia sp., E: Schizont of T. annulata in the marcrophages (arrow) and multiplying form in RBCs (arrow head), F: different forms of T. annulata (round and oval), G:mixed infection T.annulata (arrow head) and B. bovis (arrow), $\mathrm{H}$ : mixed infection A. marginale and B. bovis.

\section{DISCUSSION}

In Egypt, tick borne diseases caused by $A$. marginale, B.bigemina, B. bovis and $T$. annulata are one of the major constraints to livestock and cause serious health problems as reducing of animal productivity and economic losses. The results revealed that A. marginale had the highest prevailing rate (30.94\%) among the examined buffaloes. The peak of $A$. marginale was in winter season $(39.71 \%)$. These findings were similar to that observed by Alim et al. (2011) in Pakistan. A lower infection rate was noted by Sajid et al. (2014) (4.17\%) and a higher infection rate was encountered by Abou-Elnaga (2005) (59.3\%). The prevalence $A$. marginale was significantly higher $(P<0.05)$ at age group of $2-5$ years, which may be attributed to the age resistance which lasts up to 12 months and as the animals get older, become more susceptible to infection (Abou-El-Naga, 2005). In this study, Babesia sp. were observed in $26.60 \%$ of animals, only two species were identified (B. Bigemina in $12.07 \%$ and $B$. bovis in $8.49 \%$, mixed infection of both species was noticed in $6.04 \%$ of buffaloes). A nearly similar result was obtained by El-Fayomy et al. (2013) $(23 \%)$ in Port said. A lower incidence of $B$. bigemina was investigated by Rania (2009) $(10.44 \%)$ in Qualyubia, whereas a higher incidence of B.bovis was observed by Mahmmod (2012) (39.8\%) in Sharkia governorate. This difference could be explained by the fluctuation of parasitemia in the chronic phase of Babesia infection (Gubbels et al., 1999). 


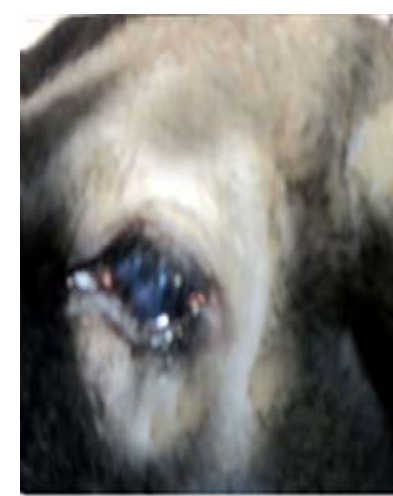

A

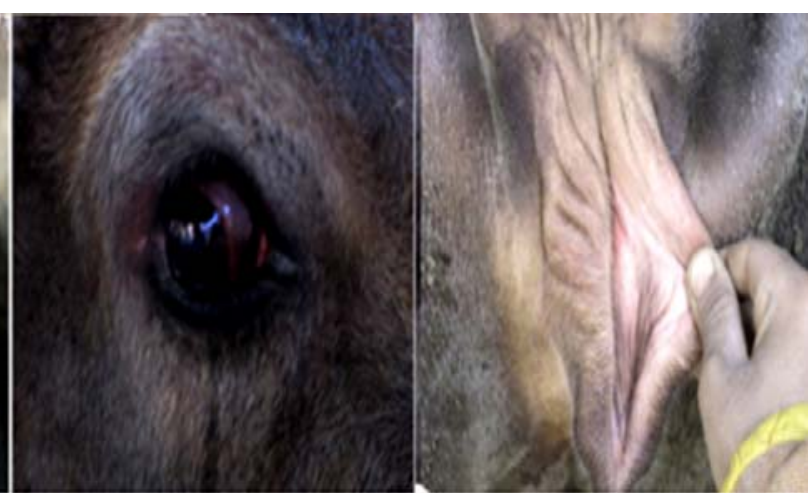

B

$\mathrm{C}$

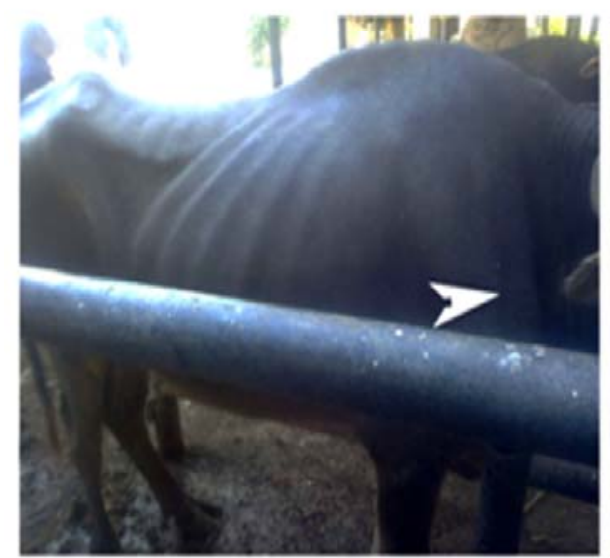

D

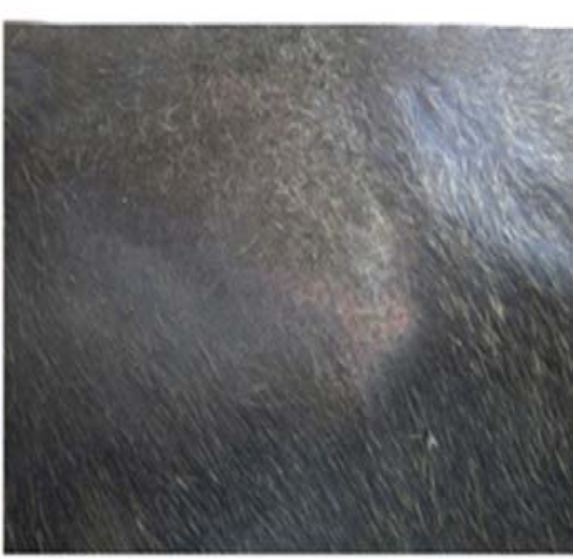

E

Plate II: The clinical sympoms recorded in clinically infected buffaloes. A: Corneal opacity, B: Lacrimation and redness of eye, C: Paleness of mucous membrane of vagina, D: Emaciation and enlargment of lymph node, E: Skin alopecia.

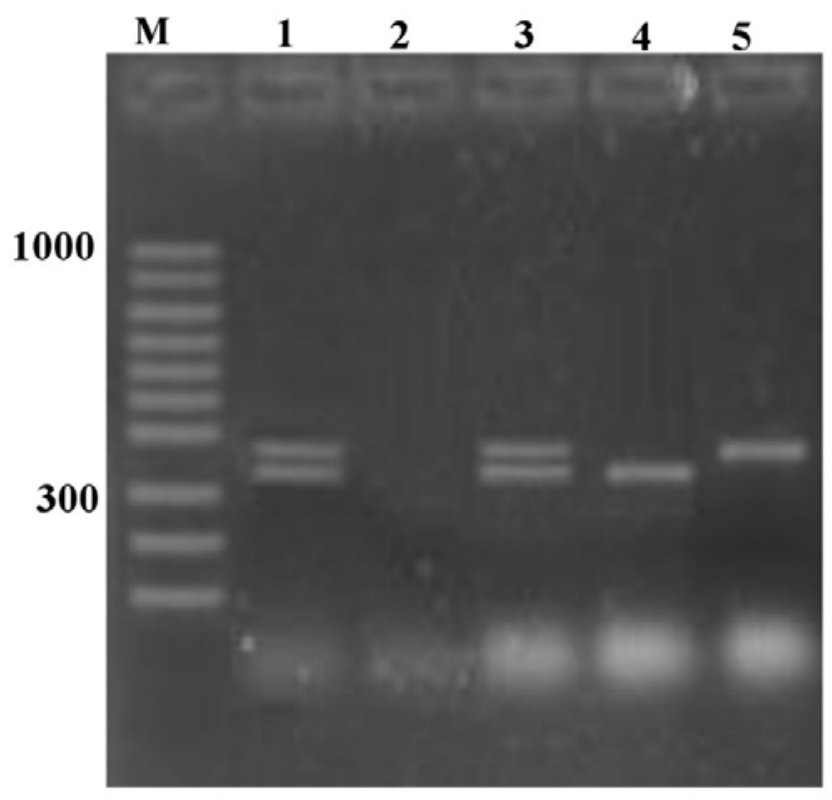

Giemsa stained thin blood smears revealed different forms of Babesia, with the dominance of the double pear shape form $(32 \%)$ inside erythrocytes. Those were 
morphologically similar to that formerly described by Homer et al., (2000), Bhikane et al., (2001), Ali (2005) and Rania (2009).

Fig. 1: PCR assay for Babesia and Theileria sp. M: DNA ladder (100 bp), lane 1: Positive control for Babesia and Theileria sp., lane 2: Negative control, lane 3: Positive mixed infection, lane 4: Positive Babesia sp., Lane 5: Positive Theileria sp.

A significantly higher infection $(P<0.05)$ of Babesia sp. in summer season (36.57\%) could be explained by the highest abundance of the ticks in the month of July (Sajid et al., 2008). This observation agreed with that previously reported by Alim et al., (2011). Conversely, El Moghazy et al. (2014) established a highest infection rate for Babesia in autumn in the same area of study. This variation may be caused by the frequent use of acaricides and antipiroplasmid drugs by the owners at intervals that has an effect on the parasite prevalence in different seasons (Safieldin et al., 2010).

An observed increase of Babesia infection with increasing animal age, where a significant difference was recorded at age of $2-5$ years $(P<0.05)$. This was mainly due to the postponed infection caused by restriction of calf movement by keeping them indoors, which is practiced by $86.5 \%$ of the farmers (Rubaire-Akiiki, 2004). Females were significantly $(\mathrm{P}<0.05)$ more susceptible $(34.06 \%)$ to Babesia sp. than males $(22.70 \%)$, this came in agreement with the results of Alim et al. (2011) and Atif et al. (2012).

The low prevalence of $T$. annulata recorded in this study $(2.08 \%)$ were consistent with other studies in Egypt (El-Moghazy, 2011 and Elsify et al., 2015), while a higher incidence was reported by Ghanem et al.(2013) (23.82\%).The prevalence of Theileria annulata was significantly higher $(\mathrm{P}<0.05)$ during summer $(2.99 \%)$, this was previously observed by El Mentenawy, (2000) and Alim et al., (2011) in cattle, while El-Moghazy (2011) reported a higher rate among buffaloes in spring. It was also noted in the study that adult buffaloes were more prone to theileriosis than their calves, which as well be explained by the age dependent immunity to Theileria and Babesia sp. infection (Norval et al., 1992 and Mahoney and Ross, 1972). The absence of Theileria infection in male buffaloes investigated in this study as compared to female could be ascribed to the immunosuppression status of female during pregnancy and/ or lactation (Kocan et al., 2010). T.annulata piroplasms were identified by their round and oval shape forms which were more common than rod and comma shapes, which are the common forms of T. parva infection (koch,1898).

The molecular prevalence based on PCR amplification of Babesia and Theileria DNA in the blood of 100 buffaloes proved to be microscopically negative, showed a positive infection in $25 \%$ and $12 \%$ of buffaloes respectively and mixed infection was noticed in $5 \%$ of buffaloes. The high infection rate of Babesia sp. as compared to Theileria sp. could be attributed to carrier animals, which are known to exhibit fluctuating low parasitemia which sometimes even escapes detection (RosGarcía et al; 2013). Generally, PCR was more sensitive for the detection Babesia and Theileria infections in subclinical, acutely infected and carrier animals, which were difficult to be detected by conventional microscope.

\section{CONCLUSIONS}

The high prevalence of Anaplasma marginale and piroplasmid infections, besides, the presence of the infection among apparently healthy animals indicates that these diseases are prevalent among buffaloes in Qualyubia governorate, Egypt, with the occurrence of carrier cases which act as a main source of infection for ticks. PCR assay provided more accurate data on the prevalence of Babesia and Theileria infections, allowed direct identification of carrier cases and diagnosis of piroplasmosis in animals in the early phase, which is very helpful for epidemiological investigations and surveillance programs. 


\section{ACKNOWLEDGMENT}

We would like to appreciate the support of www.bu.edu.eg and www.eul.edu.eg. Special thanks to the Excellence Center of Scientific Research (CESR) of Veterinary Medicine that funded by Benha University and Management Supporting Excellence (MSE).

\section{REFRERENCES}

Abou-EL-Naga, T.R., Abdou, T.A. Mona, A.M. 2005. Clinicopathlogical Studies on Theileria annulata infection in Siwa Oasis, Egypt. BeniSuef Vet Med J, 15(2): 40-46.

Adaszek, L., Winiarczyk, S. 2008. Molecular characterization of Babesia canis canis isolates from naturally infected dogs in Poland. Vet Parasitol, 152: 235-241.

Ali, A.A.M. 2005. Clinic pathology studies on blood Babesiosis with trials of treatment in cattle. M.V.Sc thesis, clinical pathology, Fac. Vet. Med., Benha University, Egypt.

Alim, M.A., Das, S., Roy, K., Masuduzzaman, M., Sikder, S., Hassan, M.M., Siddiki, A.Z., Hossain, M.A. 2011. Prevalence of hemoprotozoan diseases in cattle population of Chittagong division, Bangladesh. Pak Vet J, 32(2): 221224.

Almeria, S., Castella', J., Ferrer, D., Ortuño, A., Estrada-Peña, A., Gutierrez, J.F. 2001. Bovine piroplasm in Minorca (Balaric Island Spain): a comparison of PCR-based and light microscopy detection. Vet Parasitol, 99: 249-259.

Altay, K., Aydin, M.F., Dumanli, N., Aktas, M. 2008. Molecular detection of Theileria and Babesia infections in cattle.Veterinary Parasitology, 158: 295-301.

Atif, F.A., Khan, M. S., Iqbal, H.J., Arshad, G. M., Ejaz, A., Sami, U. 2012. Prevalence of Anaplasma marginale,
Babesia bigemina and Theileria annulata infections among cattle in Sargodha District, Pakistan. African Journal of Agricultural Research, 7(22): 3302-3307.

Baur, D.J., Ackerman, G.P., Toro, G. 1974. Clinical Laboratory method $8^{\text {th }}$ edition Bhikane A.U., Narladkar B.W., Anantwar L.G., Bhokre A.P. 2001.Epidemology, clinicopahology and treatment of Babesiosis in cattle. Indian Vet J, 78(8): 726-729.

Bhikane, A.U., Narladkar, B.W., Anantwar, L.G., Bhokre, A.P. 2001 Epidemiology, clinic-pathology and treatment of Babesiosis in cattle. Indian Vet J, 78 (8):726-729.

Böse, R., Jorgensen, W.K., Dalgliesh, R.J., Friedhoff, K.T., de Vos, A.J. 1995. Current state and future trends in the diagnosis of babesiosis. Vet Parasitol, 57:61-74.

Chaudhry, Z.I., Suleman, M., Younus, M., Aslim, A. 2010. Molecular Detection of Babesia bigemina and Babesia bovis in Crossbred Carrier Cattle through PCR. Pakistan J Zool, 42(2): 201-204.

Coles, E.A. 1986. Veterinary clinical pathology. $\quad 4^{\text {th }}$ Ed.Philadelphia, London,Tokoyo, Sydney, Hong Kong.

El-Fayomy, A.O., Ghoneim, A. M., AbuSamak, O.A., Khidr, A. A. (2013). Contribution of Babesia to the Illness of Cows in Port Said Governorate, Egypt. Global Veterinaria, 11 (1): 118-122.

El Mentenawy, T.M. 2000. Prevalence of blood parasites among cattle at the central area of Saudi Arabia. Vet Parasitol, 87(2-3): 231-236.

El-Moghazy, F.M. 2011. Impact of Parasitic Infestation on Ovarian Activity in Buffaloes-Heifers with Emphasis on Ascariasis in Egypt. World Journal of Zoology, 6 (2): 196203.

El Moghazy, H.M., Ebied, M.H, Mohamed, G. A., Amr, A. E. 2014. 
Epedimiological studies on babesiosis and theileriosis in Qualyubia Governorates. Benha Veterinary Medical Journal, 27(1): $36 \square 48$

Elsify, A., Sivakumar, T., Salsma, A., ELKhtam, A., Rizk, M., Mosuab, O., Sultan, K., ELsayed, S., Igarashi, I., Yokoyama, N. 2015. An epidemiological survey of bovine babesiosis and theileriosis in Egypt. Parasitol Int, 64(1):79-85.

Ghanem, M. M., Omnia, M. A., Nabil, M. A. 2013. Clinico-Biochemical, Serological and Molecular Study on Tropical Theileriosis in Egyptian Water Buffaloes (Bubalus bubalis) Alexandria Journal of Veterinary Sciences, 39:1-11

Goff, L., Johnson, W.C., Molloy, J.B., Jorgensen, W.K., Waldron, S.J., Figueroa, J.V., Matthee, O., Adams, D.S., McGuire, T.C., Pino, I., Mosqueda, J., Palmer, G.H., Surez, C.E., Knowles, D.P., McElwain, T.F. 2008. Validation of a competitive enzyme-linked immunosorbent assay for detection of Babesia bigemina antibodies in cattle. Clin Vaccine Immuno, 15:1316-1321.

Gubbels J.M., de Vos, A.P., Van der Weide, M., Viseras, J., Schouls, L.M., de Vries, E., Jongejan, F.1999. Simultaneous detection of bovine Theileria and Babesia species by reverse line blot hybridization. J Clin Micobiol, 37: 1782-1789.

Homer M.J., Aguilar-Delfin I., Telford $3^{\text {rd }}$

S.R., Krause P.J., Persing D.H.,2000. Babesiosis. Clin. Microbiol. Rev.13, 451-469.

Iseki, H., Zhou, Z., Kim, C., Inpankaew, T., Sununta, C., Yokoyama, N., Xuan, X., Jittapalapong, S., Igarashi, I. 2010. Seroprevalence of Babesia infections of dairy cows in northern Thailand. Vet Parasitol, 170: 193196.

Kocan, K. M., E. F. Blouin, and A. F. Barbet. 2000. Anaplasmosis control: past, present and future. Ann N Y Acad Sci, 916: 501-509.

Kocan, K.M., De la Fuente, J., Bouin, E.F., Coetzee, J.F., Ewing, S.A. 2010. The natural history of Anaplasma marginale. Vet Parasitol, 167: 95-107.

koch, R., 1898. Reiseberichte über Rinderpest, Bubonenpest in Indien undAfrika, Tsetse-oder Surrakrankheit, Texasfieber, tropische

Malaria,Schwarzwasserfieber. Berlin: J. Springer.

Norval, R.A.I., Perry, B.D., Young, A.S. 1992. The Epidemiology of Theileriosis in Africa. London, Academic Press. 13-42, 67-68.

Mahmmod, Y.S. 2012. Molecular detection of natural Babesia bovis infection from clinically infected and apparently healthy water buffaloes (Bubalus bubalis) and cross breed cattle. Journal of Buffalo Science, 1 (1): 55-60.

Mahoney, D.A., Ross, D.R. 1972. Epizootiological factors in the control of bovine babesiosis. Aust Vet J, 48: 292-298.

Mehlhorn, H., Schein, E., 1984. The piroplasms: life cycle and sexual stages. Adv Parasitol, 23: 37-103.

Rania, Y.E. 2009. Some studies on diagnosis on babesiosis. M.V.Sc. thesis, Faculty of Veterinary Medicine, Benha University, Benha, Egypt.

Ros-García. A., Barandika, F.J., GarcíaPérez, L.A., Juste A.R. 2013. Assessment of exposure to piroplasms in sheep grazing in communal mountain pastures by using a multiplex DNA bead-based suspension array. Parasites \& Vectors, 6: 277.

Rubaire-Akiiki, C., Okello-Onen, J., Nasinyama, G.W., Vaarst, M. Kabagambe, E.K., Mwayi, W. Musunga, D., Wandukwa, W. 2004. The prevalence of serum antibodies to 
tick-borne infections in Mbale district,Uganda: The effect of agroecological zone, grazing management and age of cattle. J Ins Sci, 4(8): 1-8.

Safieldin, A. M., Gadir, A.E., Elmalik, K.H. 2010. Factors affecting seasonal prevalence of blood parasites in dairy cattle in Omdurman locality, Sudan. Vet Parasitol, 3(3): 32-37.

Sajid, S. M, Iqbal, Z., Khan, N.M. Muhammad G. 2008. Point Prevalence of Hard Ticks (Ixodids) Infesting Domestic Ruminants of Lower Punjab, Pakistan. Int J Agri Biol, 10: 349-51.
Spielman, A.,Wilson, M.L., Levine, J.F., Piesman, J. 1985. Ecology of Ixodes damminiborne human babesiosis and lyme disease. Annu Rev Entomol, 30:439-460.

Steel, R. G., Torie, G. H. 1981. Principles and procedures of statistics $2^{\text {nd }}$ Mcgraw-Hill International Book Company. London pp. 60-64.

Weiland, G., Reiter, I. 1988. Methods for measurement of the serological response to Babesia. In:RisticM(ed) Babesiosis of domestic animals and man. CRC Boca Raton, pp.143-162 